\title{
Crushing behavior of kenaf fiber/wooden stick reinforced epoxy hybrid "green" composite elliptical tubes
}

\author{
Mohamed Alkateb'), S.M. Sapuan ${ }^{1), *)}$,Z. Leman ${ }^{1)}$, M. Jawaid ${ }^{2)}$, M.R. Ishak ${ }^{3)}$ \\ DOI: dx.doi.org/10.14314/polimery.2018.6.4
}

\begin{abstract}
In this paper, an investigation on crushing behavior of kenaf fiber/wooden stick reinforced epoxy hybrid composite elliptical tubes is presented. Kenaf fiber reinforced epoxy elliptical composite tubes, unsupported and supported by wooden sticks $(4,6$ and 8$)$, were fabricated using hand lay-up process. The crushing tests were performed at a constant speed of $20 \mathrm{~mm} / \mathrm{s}$ to explore the potential effect of wooden sticks on the specific energy and mechanical behavior of kenaf fiber reinforced epoxy composite elliptical tubes. As a result of the study, it was found that the load carrying capacities of kenaf fiber reinforced epoxy composite tubes were gradually increased with the number of wooden sticks. Generally, the investigation showed that kenaf fiber reinforced epoxy composite elliptical tubes supported by wooden sticks demonstrated superior specific energy absorption and crashworthiness compared to the composite tubes unsupported. Further, the results also revealed that all specimens have failed in longitudinal failure modes. In this regard, an elliptical composite tube supported by 8 wooden sticks exhibited the best energy absorption capability.
\end{abstract}

Keywords: kenaf fiber mat, biocomposites, specific energy absorption, epoxides, crushing behavior, wooden sticks.

\section{Wytrzymałość na zgniatanie rur eliptycznych z „zielonych" kompozytów epoksydowych wzmacnianych włóknami kenafu i prętami drewnianymi}

\begin{abstract}
Streszczenie: Przedstawiono wyniki badań odporności na zgniatanie eliptycznych rur wykonanych metodą laminowania ręcznego z hybrydowych kompozytów żywicy epoksydowej z włóknami kenafu, wzmacnianych 4, 6 lub 8 prętami drewnianymi. Testy zgniatania prowadzono przy stałej szybkości $20 \mathrm{~mm} / \mathrm{s}$, w celu oceny potencjalnego wpływu wzmacniających prętów drewnianych na energię właściwą oraz właściwości mechaniczne kompozytów. Stwierdzono, że zdolność do przenoszenia obciążeń przez rury kompozy towe zwiększała się ze wzrostem liczby prętów wzmacniających. Badania wykazały, że wzmocnienie prętami drewnianymi rur eliptycznych z kompozytów żywicy epoksydowej z włóknami kenafu wpływa na zwiększenie zdolności absorpcji energii oraz odporności na zderzenia. Wszystkie próbki ulegały zniszczeniu w kierunku wzdłużnym. Największą zdolność pochłaniania energii wykazywała rura kompozytowa wspierana przez 8 prętów drewnianych.
\end{abstract}

Słowa kluczowe: mata z włókien kenafu, biokompozyty, absorpcja energii, epoksydy, odporność na zgniatanie, pręty drewniane.

In recent years, interest in polymer composite materials has increased due to their advantages over monolithic materials [1]. Composite materials are defined as engineering materials that exist as a combination of two

\footnotetext{
1) Universiti Putra Malaysia, Department of Mechanical and Manufacturing Engineering, 43400 UPM, Serdang, Selangor, Malaysia.

2) Universiti Putra Malaysia, Laboratory of Biocomposite Technology, Institute of Tropical Forestry and Research Products (INTROP), 43400 UPM, Serdang, Selangor, Malaysia.

3) Universiti Putra Malaysia, Departments of Aerospace Engineering, 43400 UPM, Serdang, Selangor, Malaysia.

*) Author for correspondence; e-mail: sapuan@upm.edu.my
}

or more materials that provides better properties than individual components alone can be done [2]. Reinforcement is generally responsible for reinforcing the composites and improves their mechanical properties. All the different fibers and methods of support in the fiber reinforcements have influence on the properties of the composite materials. Natural fibers such as kenaf, jute, banana, hemp, bagasse, and oil palm are superior to synthetic fibers in terms of renewability, cost, density, biodegradability, etc. [3]. In addition, natural fiber composite materials have the potential to be widely applied to energy absorption structures and in defense industry [4]. The main application areas of natural fiber composites are the automotive and building industries in which 
they are used in structural applications as fencing, decking, outdoor furniture, window parts, roofline products, door panels, etc. [5-9]. In this study a natural fiber (kenaf fiber) is used as reinforcement for elliptical cone epoxy composites.

The energy absorption capacity of composite materials is important for improving the safety of human beings in the event of a car crash. Energy absorption depends on many parameters such as fiber type, matrix type, fiber structure, specimen shape, processing condition, fiber volume fraction, test speed, etc. Changes in these parameters can cause subsequent changes in the specific energy absorption $\left(E_{S}\right)$ of the composite material up to tow [10].

Alkateb et al. [11] experimentally examined the behavior of a composite elliptic thin-walled cone subjected to quasi-static axial crushing. They concluded that the collapse behavior of elliptical cones is very sensitive to vertex angle change. Alkbir et al. [12] studied the effect of geometry on the impact resistance parameters of natural kenaf fiber reinforced composite hexagonal tubes. Different hexagonal angles were used during the processing of composite with kenaf fiber mat into a hexagonal shape. Experimental results revealed that the tubes with an angle of $60^{\circ}$ had the highest energy absorption performance due to the local buckling mode. Misri et al. [13] reported experimental and simulation studies to investigate the behavior of composite hollow shafts. It focuses specifically on the different winding angles and the maximum torsional capacity of the composite hollow shaft for aluminum reinforcement. The results showed that the maximum static torsional capacity of the fiber-reinforced unsaturated polyester composite with kenaf yarn wound at $45^{\circ}$ performed better compared to the yarn wound at $90^{\circ}$ and that the presence of aluminum significantly improved torsional properties of the composites.

Most studies on the crashworthiness parameters have focused on determining the effects of type and fiber orientation [14], structural applications [15] and low velocity impact [16]. Mahdi et al. [17] examined the effect of conical angle on fiber type and its crushing behavior and performance. The crushing mechanism strongly depends on the fiber type different from the cylinder cone vertex angle changed to failure mode. Warrior et al. [18] studied the influence of tube geometry on the crashworthiness performances of composite tubes. In their study, randomly orientated non-woven kenaf fibers were hardened into hexagonal tubes. They found that changes in hexagonal tube angle affect impact crashworthiness parameters in various different failure modes. Davoodi et al. [19] checked the mechanical properties of a hybrid kenaf/glass reinforced epoxy composite for bumper bars for traveller autos. They discovered preferences as far as mechanical properties contrasted with other normal bumper bar materials. However, the effect properties are still beneath the coveted level. Eshkoor et al. [20] found that the value of energy absorption decreases irrespective of the trigger mechanism as the length of the tube increases, they conducted a comparative study on the impact resistance of the natural silk/epoxy composite tube of the fabric and used twelve layers of silk fabric and took into consideration the length of the three tubes.

A study was conducted on quasi-statically crushed composite in the transverse direction. It was found that orientation of fibers is not an important key factor in increasing the specific energy absorption rate and force ratio [21]. The number of layer was increased, the absorbed energy was also increased, through test crushing coaxial to obtain the force-displacement curves, and analysis of the test results showed that varying fiber orientations for a single layer of fibers had no significant effect on the energy absorption performance. Kenaf yarn fiber was also hybridized with steel tubes [22]. Generally, composite materials have demonstrated the ability to retain important safety capabilities during vehicle crash.

The previous studies concerned crashworthiness performance of the composite tubes fabricated using non-woven, mat, woven and yarn kenaf fibers for crashworthiness applications. However, there is still lack of work on the crashworthiness of mat kenaf fiber composites with the use of additional supports such as wooden sticks. In this research, quasi-static tests under axial compression were performed and the energy absorption capacity of kenaf mat reinforced epoxy composite elliptical tubes unsupported and supported by wooden sticks was investigated. The parameters measured include the maximum crushing load, the maximum stress, the total absorbed energy, the specific absorbed energy, and the crushing force efficiency.

\section{EXPERIMENTAL PART}

\section{Materials}

The as-received kenaf fiber mats with the thickness of 3.5-4.0 mm were supplied by Tazdiq Enterprise, Malaysia. A set of wooden sticks for supporting kenaf mats was purchased from a local hardware store. Figure 1 shows kenaf mats and wooden sticks used in this study and how to install wooden sticks.

The matrix used was a combination of D.E.R. ${ }^{\mathrm{TM}} 331^{\mathrm{TM}}$ liquid epoxy resin and Joint Mine 950-3S as hardener/curing.

a)

b)

c)

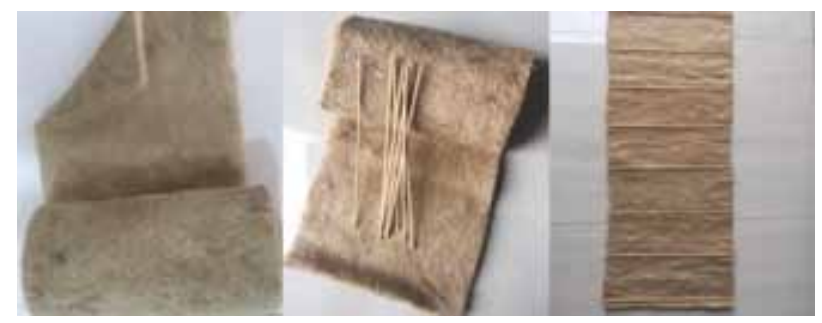

Fig. 1. a) Kenaf mats, b) kenaf mats and wooden sticks, c) installing of wooden sticks 


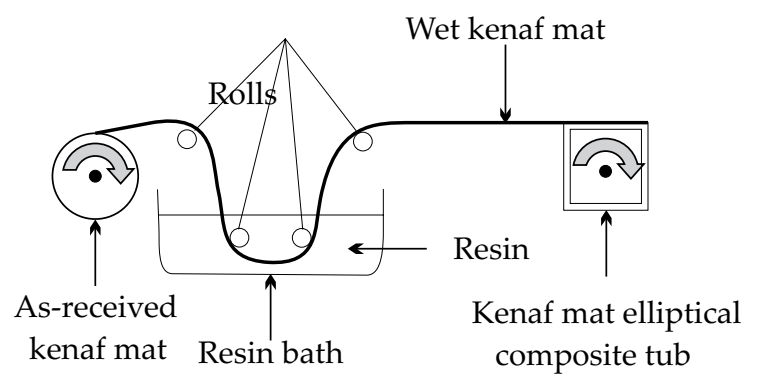

Fig. 2. Schematic diagram of the winding process of kenaf mat composite elliptical tube

\section{Fabrication process of elliptical composite tubes}

Initially, kenaf mats were cut to a desired size. The kenaf fiber mats containing moisture were dried under the sun at 25 to $35{ }^{\circ} \mathrm{C}$ for one hour. The polymer matrix was prepared by mixing epoxy resin and hardener at the ratio of $2: 1$ and they were thoroughly mixed for 5 to 10 minutes before being applied to the fiber mats. The composite tubes were fabricated by hand lay-up process using a hand-held machine. Figure 2 shows schematic diagram of the winding process for the composite tubes, both supported with wooden sticks and unsupported, the wooden sticks were placed evenly on the kenaf fiber mats. The hand lay-up process was carried out using a roller to squeeze out excess resin with both resin and kenaf fibers wound around an elliptical tube mold. As soon as the composite tubes were fully hardened, they were removed from the mold. The process of fabricating the composites was continued until the composites were dried and cured by leaving them at room temperature for approximately 48 hours. Stages of manufacturing and processing test samples as shown in Fig. 3.

Both top and bottom bases of the composite tubes were trimmed to remove the unnecessary fibers and hardened resin. In this work, twelve composite tubes with the length of $230 \mathrm{~mm}$ and the thickness depended on the number of layers were produced. Mat kenaf fiber reinforced epoxy composite elliptical tubes were made in two layers of kenaf fiber mats with the thickness of $9 \mathrm{~mm}$. Different numbers of wooden sticks (4, 6 and 8) were used for supporting the composites tubes, denoted respectively as (KRCET-0ws), (KRCET-4ws), (KRCET-6ws) and (KRCET-8ws). For each test, three samples were replicated.

\section{Methods of testing}

\section{Quasi-static compression tests}

The quasi-static crush test was conducted between parallel steel plates of a universal testing machine (Instron AG-IS, 25 tones). The elliptical composite tubes were placed vertically and compressed quasi-statically under a constant cross-head displacement of $20 \mathrm{~mm} / \mathrm{min}$. About 70 to $80 \%$ of the height of the tube was crushed. The load versus displacement curve for each compound

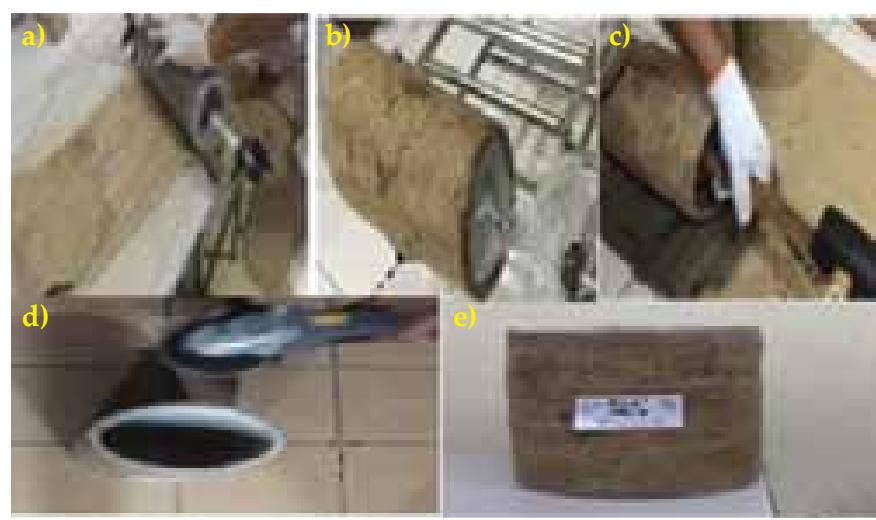

Fig. 3. a) Wet and wrapped kenaf mat around the mold, b) sample left for a while to dry well, c) sample extracted from the mandrel, d) finishing the sample, e) hardened kenaf mat composite elliptical tube

condition was automatically recorded when the area under the curve represents energy absorption performance. Other important quasi-static test parameters such as average crushing load $\left(P_{m}\right)$ and initial crushing load $\left(P_{i}\right)$ loads were examined. Initial crushing load $\left(P_{i}\right)$ was defined as the maximum load of elastic deformation before the composite showed signs of initial failure. The average crushing load $\left(P_{m}\right)$ was obtained by averaging the maximum and minimum loads around the variable region, and a typical elliptical tube under investigation is shown in Fig. 4.

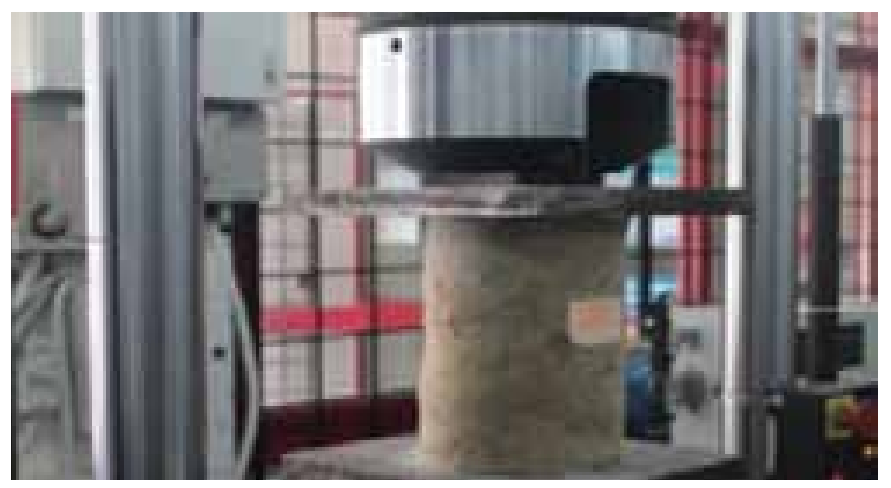

Fig. 4. Typical composite elliptical tube under investigation

\section{Crashworthiness performance}

From the load-displacement response of the composite sample, crashworthiness resistance parameters were obtained. They are useful for comparing different composites for their load carrying capacity and energy absorption capacity with various number of wooden sticks $(0,4,6$ and 8). Table 1 shows the quasi-static crush test parameters of a mat kenaf fiber reinforced epoxy composite elliptic tubes (KRCET- $x$ ws) with respect to the following important parameters: crush force efficiency (CFE), mean crushing stress $(\sigma)$, initial failure indicator (IFI), specific energy absorption $\left(E_{S}\right)$, volumetric energy absorption capability $\left(E_{V}\right)$. 
T a b l e 1. Important crushing performance parameters of composite elliptical tubes

\begin{tabular}{c|c|c|c|c|c|c|c|c}
\hline Sample & $P_{i^{\prime}} \mathrm{kN}$ & $P_{c^{\prime}} \mathrm{kN}$ & $P_{m^{\prime}} \mathrm{kN}$ & $I F I$ & $C F E$ & $E_{N S^{\prime}} \mathrm{kJ} /\left(\mathrm{kg} \cdot \mathrm{m}^{2}\right)$ & $\sigma, \mathrm{MPa}$ & $E_{V^{\prime}} \mathrm{MJ} / \mathrm{m}^{3}$ \\
\hline KRCET-0ws & 19.19 & 13.72 & 6.99 & 1.40 & 0.51 & 309.09 & 1.69 & 0.31 \\
KRCET-4ws & 10.67 & 9.40 & 8.78 & 1.13 & 0.81 & 413.33 & 2.13 & 0.43 \\
KRCET-6ws & 11.87 & 10.86 & 9.26 & 1.09 & 0.98 & 429.98 & 2.24 & 0.41 \\
KRCET-8ws & 13.83 & 11.01 & 12.40 & 1.26 & 1.13 & 570.73 & 3.00 & 0.57 \\
\hline
\end{tabular}

Crush force efficiency (CFE) is the ratio between the initial crush failure load and the average crush load [23]. It is calculated as:

$$
C F E=\frac{P_{i}}{P_{m}}
$$

where: $P_{i^{\prime}} P_{m}$ - the initial and the average crushing loads, respectively.

The mean crushing stress $(\sigma, \mathrm{MPa})$ - average crushing load $P_{m}$ divided by the original material cross-sectional area $A\left(\mathrm{~mm}^{2}\right)$ :

$$
\sigma=\frac{P_{m}}{A}
$$

Initial failure indicator IFI should be as close as possible to 1 , which is actually difficult to achieve:

$$
I F I=\frac{P_{i}}{P_{c r}}
$$

where: $P_{c r}$ - the critical crushing load.

The average energy $(E)$ absorbed as represented by the areas $\left(s_{i}\right)$ under the load-displacement curve is a function of specimen cross-sectional area, material density, and the crush distance:

$$
E=\sum_{i=1}^{N} P_{i} \frac{s_{i+1}-s_{i-1}}{2}
$$

The total work $\left(W_{t}\right)$ or energy absorbed by crushing the composite specimen in the area under the load-displacement curve is as follows:

$$
W_{t}=\int_{s_{i}}^{s_{b}} P \mathrm{~d} s
$$

where: $P-$ a crushing load, $\mathrm{d} s-$ a small element of crushed distance.

$$
W_{t}=\int_{s_{i}}^{s_{b}} P_{m} \mathrm{~d} s=P_{m}\left(s_{b}-s_{i}\right)
$$

where: $s_{b^{\prime}} s_{i}$ - the crush distances, $P_{m}$ - the average crush load as indicated.

The specific energy absorbed during the axial crushing of the tubes, which is equal to the area under the load-displacement curve, is evaluated as:

$$
E_{S}=\frac{1}{A h \varrho} \sum_{i=1}^{N-1} P_{i} \frac{s_{i+1}-s_{i-1}}{2}
$$

The effect of cross-section area on the energy absorbed, the specific energy absorption equation can be normalized as:

$$
E_{N S}=\frac{1}{A^{2} h \varrho} \sum_{i=1}^{N-1} P_{i} \frac{S_{i+1}-s_{i-1}}{2}
$$

The volumetric energy absorption capability (i.e., energy absorbed per unit volume) is also an essential parameter for an energy absorbing system design, where the volume is volume sample before crushing. The energy absorbed per unit volume $\left(E_{V}\right)$ can be calculated as:

$$
E_{V}=\frac{E}{V}
$$

\section{RESULTS AND DISCUSSION}

\section{Load-displacement curves}

One of the main factors for measuring impact test is the load-displacement relationship of the energy absorbing device. In general, there are three different stages in the history of curves: the crash initiation stage, the crush propagation stage, and the material densification step. At the beginning of the crushing stage, elastic strain energy is accumulated in the specimen, as the load increased the total failure did not occur. The pre-crash stage is dominated by the local failure mechanism at the microscale, such as microbuckling of the compression side fibers and debonding at the fiber-matrix interface, and the wall cross-sectional area plays the biggest role in the failure of the specimen when a critical load value is reached. Normally, the fracture propagates in two ways: a catastrophic "euler buckling" way, or a progressive way to continue to absorb energy with the desired crush load.

Figure 5 shows the load-displacement curves of unsupported mat kenaf fiber reinforced epoxy composite elliptic tubes (KRCET) and the ones supported with different number of wooden sticks (ws) under quasi-static compressive load. These curves show a typical load-displacement diagram and can be divided into three main regions. The first region is a linear elastic deformation with the force linearly proportional to the displacement. When the tubes collapsed, the composite experienced a sharp descent. When the load was continued, the load with which the composite gradually collapses fluctuated. If the crushed length was about $170-180 \mathrm{~mm}$, the load increased again, but there was a slight displacement. Elsaid et al. [23] reported that the square and hexagonal shape were crushed catastrophically while circular shape showed uniform and progressive crushing mode. 


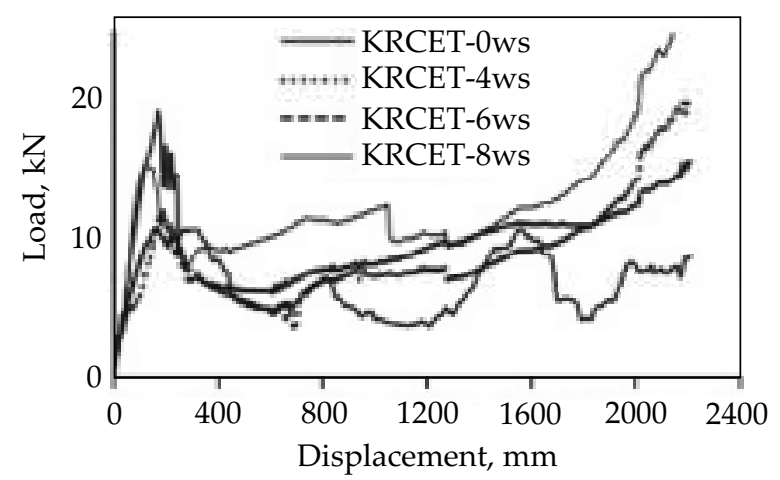

Fig. 5. Load-displacement curve of the two-layer composite elliptical tubes

Composite elliptic tubes both unsupported and supported using 4,6 and 8 wooden sticks were made. The samples containing 8 wooden sticks showed to have a higher load response compared to other samples. Composite elliptic tubes with 4 and 6 wooden sticks (KRCET-4ws, KRCET-6ws) exhibited similar load-displacement curves. In other words, although the converged results were obtained, they were better than the results obtained from the unsupported samples (KRCET-0ws). However, it was observed that the composite experienced catastrophic failure, especially in the second stage. As the number of wood sticks (supports) increased, the response of the load-displacement curve appeared to increase as expected. The effect of wood sticks supporting kenaf fiber mat/epoxy composite elliptical tube was particularly pronounced in the first region (initiation stage). The unsupported composite elliptical tubes showed a low load at the crushing propagation stage, thus reducing the area under the curve, which affects the energy absorption. It can be clearly seen from the load-displacement curve in Fig. 5, where the highest value of the first load is observed. As a result, lower impact test performance was obtained. It was also revealed that there was no significant difference in load-displacement reaction with 4,6 and 8 wooden sticks (KRCET- $x$ ws).

\section{Failure mechanisms}

From Fig. 5 the compression history of the mat kenaf fiber reinforced epoxy composite elliptic tubes is shown using different numbers of wooden sticks (4,6 and 8). It has been reported that a mat kenaf elliptical tube supported using a wooden stick fails in a different mode than unsupported composite structure, but it is symmetrical. The mat kenaf fiber reinforced epoxy composite elliptic tubes undergo compression axial test, and it shows ductile deformation without fragmentation afterwards. The composite tube generates an initial crash fracture load with the highest peaks $\left(P_{i}\right)$ at $19.19,10.67,11.87,13.83 \mathrm{kN}$, respectively (see Table 1 ). The load has increased semi-linearly before the start of matrix micro cracking. This is the highest peak (upper yield point). Fracture took place in the central region because the fibers were torn with sticks. Then, a transverse shear crack took place on the left side of the composite tube. Next, the transverse shear crack at the centre was almost faded, subsequently the elliptic tube composite cracked, the load-carrying capacity of the tube decreased, reaching a low value of $\left(P_{c r}\right)$ at $13.72,9.40,10.86,11.01 \mathrm{kN}$, respectively (as clearly seen in Table 1), when a certain distance can be inferred from the displacement axis. Also, from the typical load-displacement curve and analysis of the results for the kenaf composite tube with different number of wooden sticks the average crushing load $\left(P_{m}\right)$ values were obtained , i.e., 6.99, $8.78,9.26$ and $12.40 \mathrm{kN}$, respectively. Figure 6 shows the relationship between the number of wooden sticks and the average crushing load $\left(P_{m}\right)$, as one of the main factors of energy absorption. The failure region has the largest role in increasing the area under the curve, thus increasing the average crushing load. Finally, the lock-up region

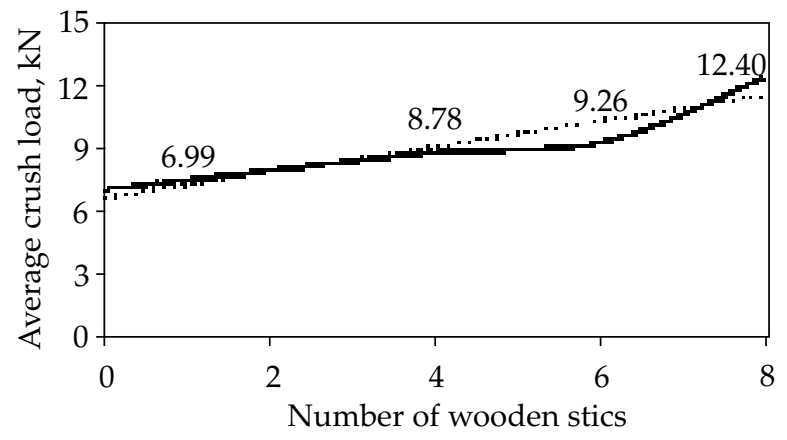

Fig. 6. Graphical relationship between number of wooden sticks and mean crush load
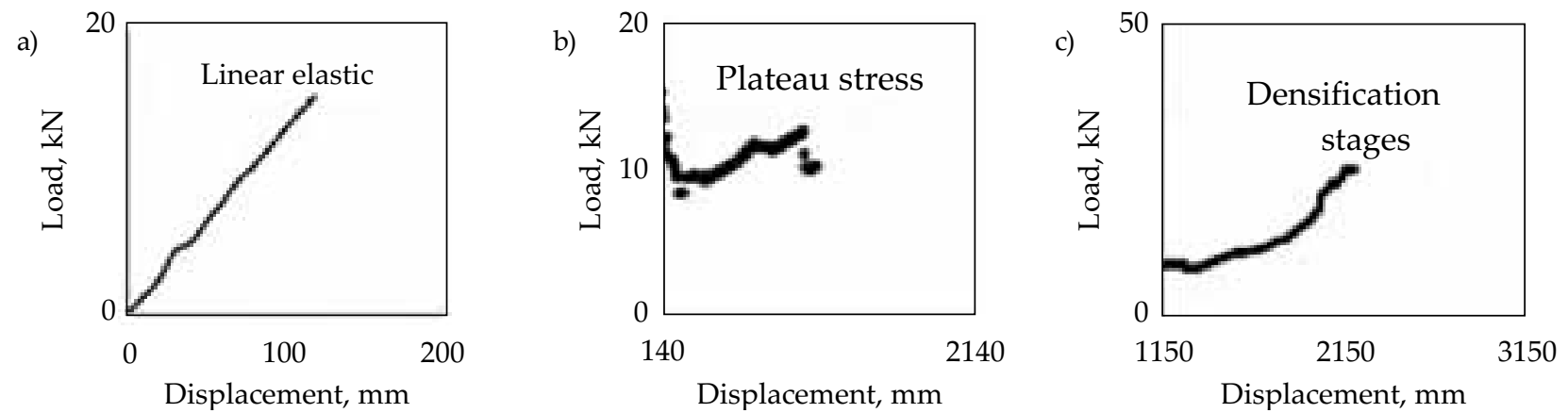

Fig. 7. Different behavior of crushing: a) linear elastic, b) plateau stress, c) densification stages of composite tubes 


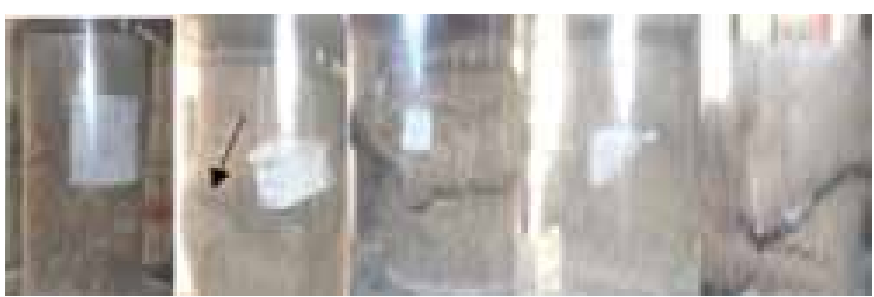

Fig. 8. Images taken during the crushing test, where the collapse took place in kenaf mat supported by wooden stick in elliptical composite tubes

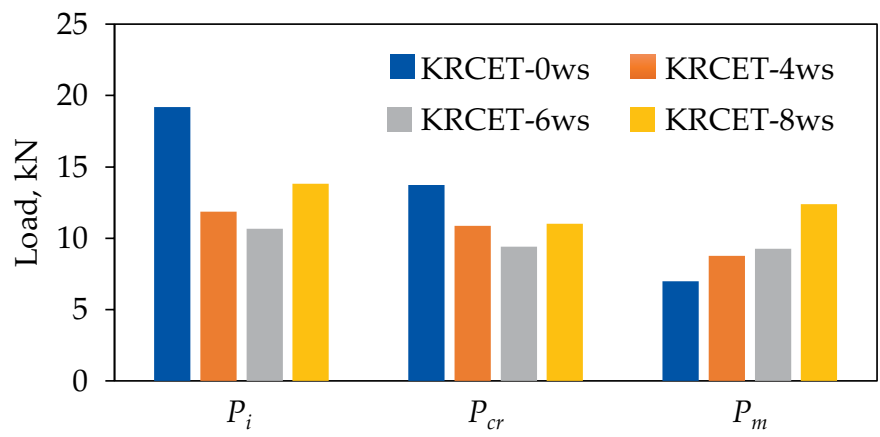

Fig. 9. Load bearing capacity for mat kenaf fiber epoxy composite elliptical tubes with different number of wooden sticks

follows the drop, the load increases non-linearly (densification stages of elliptic tubes composite).

Figure 7 shows different behavior of crushing stages of the composite tube samples; ranging from number 1 (linear elastic) until 3 (densification stage). Figure 8 shows illustrative images taken during the crushing test, where the collapse took place in kenaf mat supported by wooden stick in elliptical composite tubes.

\section{Influence of wooden sticks on load-carrying capacities}

There are four different samples of kenaf fiber reinforced epoxy composite elliptical tubes with different number of wooden sticks, i.e., 0, 4, 6 and 8 . All specimens were crushed and analyzed for crushing behavior. The first data of crushing failure load $P_{i}$ was taken and it was observed that KRCET-0ws had the highest value of $19.19 \mathrm{kN}$ com-

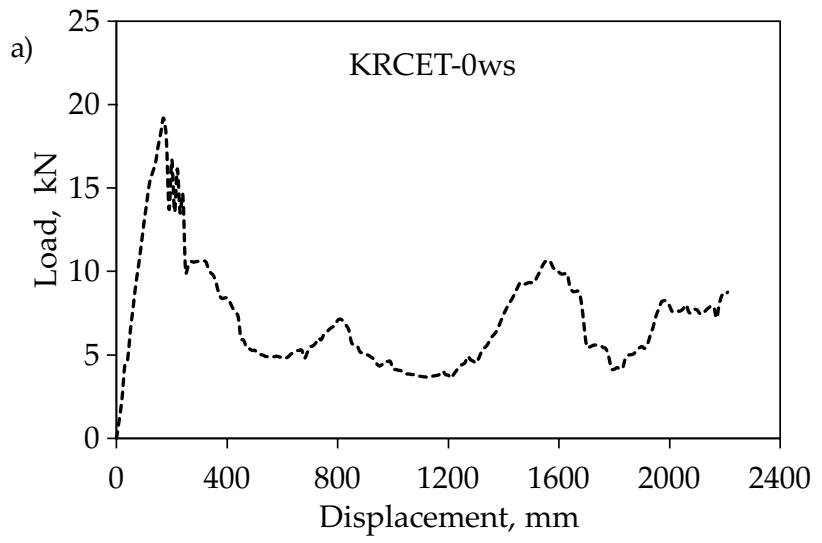

pared to other test specimens. Figure 9 is a bar chart showing the effects of the number of wooden sticks $(0,4,6,8)$ on the initial crushing load $\left(P_{i}\right)$ compared with other load values [critical crushing load $\left(P_{c r}\right)$ and average crushing load $\left.\left(P_{m}\right)\right]$ of elliptical composite tubes. Such effects of the typical load-displacement curve in composite tubes had also been studied by Elfetori et al. [24].

It indicates the effectiveness of energy absorption during fracture, which may also provide some information on the fracture mode of the cylinder tubes [25] unsupported and supported by wooden sticks (4 and 6). A similar trend was found in the elliptic composite tube supported by 8 wooden sticks (KRCET- $8 \mathrm{ws}$ ) because of crushing efficiency higher than that for unsupported one (KRCET-0ws). Figure 10 shows the behavior of KRCET-0ws and KRCET-8ws samples under the crushing test, to compare the unsupported elliptic composite tube and the one supported using the largest number of wooden sticks (8).

Mirfendereski et al. [26] conducted a parametric study and numerical analysis of empty and foam-filled thin-walled tubes under static and dynamic loadings. They found that the most energy absorption takes place by a progressive fracture of composite tubes and cones under axial load. Results show that the foam filler improved the progressive crushing process, increasing the maximum load and the absorbed energy. Fig. 11 presents a graph showing the influence of the number of wooden sticks on the values of crushing force efficiency (CFE) and mean crushing stress $(\sigma)$. A clear and consistent trend not associated with the fluctuation of crushing stress can be observed. In general, it can be inferred that the average crushing stress increases with the increase in the number of wooden sticks. Of the specimens tested, the maximum crushing stress value for the sample with 8 wooden sticks (KRCET-8ws) was $3.00 \mathrm{MPa}$, and the elliptical test tube without wooden stick (KRCET-0ws) had the lowest average crushing stress of $1.69 \mathrm{MPa}$. Reddy and Al-Hassani [27] studied the axial crushing behavior of thin extruded tubes filled with wood. Reid [28] observed that filling thin-walled metal tubes with foam improved their energy absorption capacity. Also, Hansen et al. [29] developed an optimum design for energy absorption by a thin shell

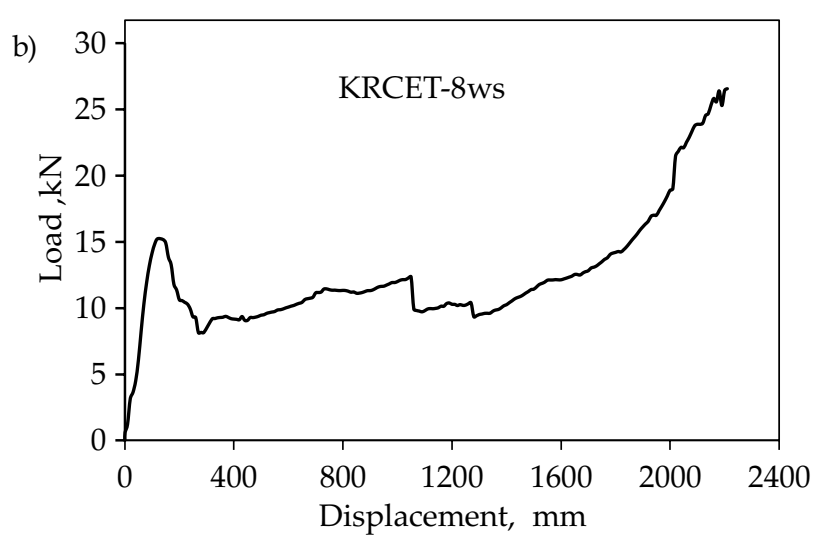

Fig. 10. Comparison of load-displacement curves and behavior of the two-layer composite elliptical tubes: a) KRCET-0ws, b) KRCET-8ws 


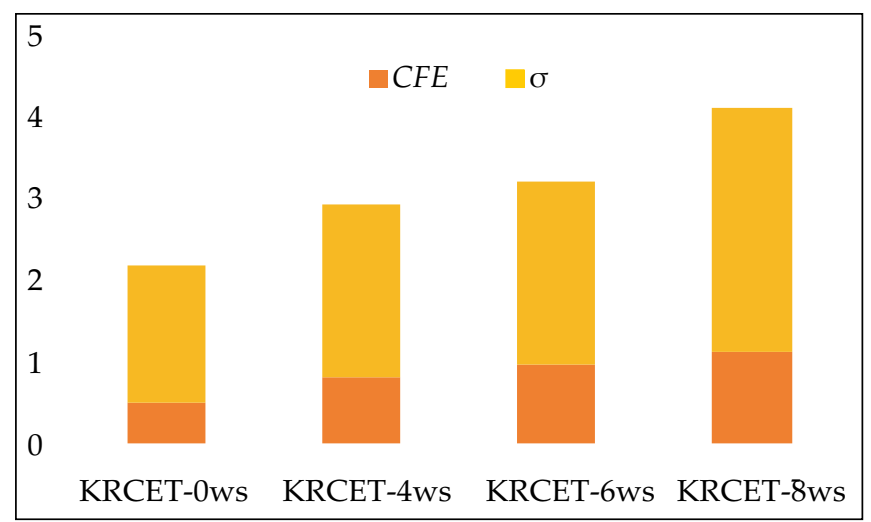

Fig. 11. Comparison of mean crushing stress ( $\sigma, \mathrm{MPa})$ and crush force efficiency $(C F E)$ values for two layers of kenaf mat composite elliptical tubes

of aluminum and filling of aluminum foam. For metallic shells, it is interesting to state that the ratio of the wall thickness to the radius is the dominant factor determining the failure mode of the fracturing mechanism.

The results show that the unsupported specimen has higher crushing peak load (upper yield point) than the specimen supported by 8 wooden sticks. The load energy below the graph of load-displacement for the specimen supported by wooden sticks is higher than for the unsupported specimen. It has proven that the specimen with 8 wooden sticks enables more energy absorption $\left[570.73 \mathrm{~kJ} /\left(\mathrm{kg} \cdot \mathrm{m}^{2}\right)\right]$ and shows the highest value of the average load $(12.40 \mathrm{kN})$, as can be seen in Fig. 10. The energy absorbed can be calculated from the area under the load-displacement curve. The crushing failure load increases with increasing number of supporting wooden sticks. A previous study by Eshkoor et al. [30] reported that the failure mode was highly dependent on the geometry of the composite tube and the manufacturing parameters.

\section{Energy absorption capability}

Figure 12 represents the effect of number of wooden sticks on the energy absorption by structural composite tubes for two layers $(t=9 \mathrm{~mm})$ of kenaf fiber mats wound in one direction. It was found that the absorbed energy increased with an increase in the number of wooden sticks. It is expected that wooden sticks toughen the composite materials, being capable of distributing the stresses across the structural wall. However, when the number of wooden sticks was increased from 4 to 6 , there was a slight drop in the absorbed energy, probably because the shear forces triggered breaking the sticks, thus lowering the energy absorption performance. However, in the case of 8 wooden sticks the energy absorption capacity was increased further.

By integrating the area under the axial load-displacement curve of the crash behavior, the specific energy capacity of the tube composite was obtained [30]. Also, the specific energy absorption of natural fiber composite

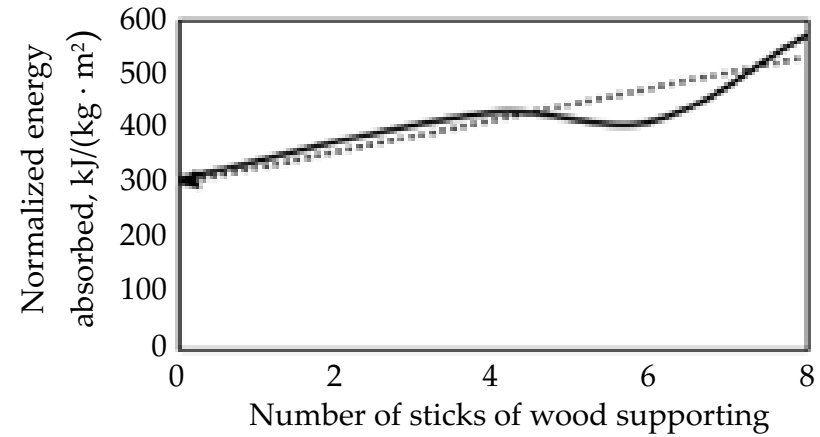

Fig. 12. Effect of number of wooden sticks on the specific energy absorption of composite elliptical tubes

tubes depends on the tube geometry and fiber reinforcement [31-33].

Figure 12 illustrates the changes in the normalized specific energy absorbed by composite elliptical cones with increasing numbers of wooden sticks.

The composite supported with 8 wooden sticks (KRCET-8ws) gave the highest specific energy capability $\left[570.73 \mathrm{~kJ} /\left(\mathrm{kg} \cdot \mathrm{m}^{2}\right)\right]$ among the investigated samples. The outcomes such as peak load, average load and specific energy absorption values of composite elliptical tubes are displayed in Table 1. Similar results were also reported in other studies [34, 35].

\section{CONCLUSIONS}

Quasi-static crushing behavior of various kenaf fiber mat reinforced epoxy composite elliptical tubes were studied in this paper. It has been proved that the addition of supporting wooden sticks to kenaf fiber reinforced polymer composite tubes can have a significant influence on the energy absorption capabilities of the material. The experiments showed that by increasing the number of wooden sticks it is possible to change the mechanism of crash, and therefore, control the energy absorption characteristics of the composite. The main conclusions that could be drawn from this investigation are:

- Addition of wooden stick reinforcement to kenaf fiber/epoxy elliptical composite tubes leads to an increase in energy absorption capabilities of the structure.

- The possible reason of this phenomenon was failure mechanism started with the wall disintegration before it was crumbled.

- The transition from brittle to ductile fracture mode was clearly demonstrated as a main reason for the increased energy absorption capability.

- The change in the number of wooden sticks in the supported elliptical composite cones affects crashworthiness parameters.

\section{ACKNOWLEDGMENTS}

The authors acknowledge the Ministry of Higher Education, Malaysia for funding this work through HiCoE grant No. 6369107. 


\section{REFERENCES}

[1] Tang S.H., Kong Y.M., Sapuan S.M. et al.: Journal of Materials Processing Technology 2006, 171, 259. http://dx.doi.org/10.1016/j.jmatprotec.2005.06.075

[2] Hambali A., Sapuan M.S., Ismail N., Nukman Y.: Journal of Central South University of Technology 2010, 17, 244. http://dx.doi.org/10.1007/s11771-010-0038-y

[3] Anwar U.M.K., Paridah M.T., Hamdan H. et al.: Industrial Crops and Products 2009, 29, 214.

[4] Yahaya R., Sapuan S.M., Jawaid M. et al.: Materials \& Design 2015, 67, 173. http://dx.doi.org/10.1016/j.matdes.2014.11.024

[5] Sahari J., Sapuan S.M., Zainudin E.S., Maleque M.A.: Carbohydrate Polymers 2013, 91, 1711. http://dx.doi.org/10.1016/j.carbpol.2012.11.031

[6] Zainudin E.S., Sapuan S.M., Abdan K., Mohamad M.T.M.: Materials \& Design 2009, 30, 557. http://dx.doi.org/10.1016/j.matdes.2008.05.060

[7] Rashdi A.A.A., Sapuan S.M., Ahmad M.M.H.M., Khalina A.: Journal of Food, Agriculture and Environment 2009, 7, 908.

[8] AL-Oqla F.M., Sapuan S.M., Anwer T. et al.: Synthetic Metals 2015, 206, 42. http://dx.doi.org/10.1016/j.synthmet.2015.04.014

[9] El-Shekeil Y.A., Sapuan S.M., Khalina A., Zainudin E.S.: Journal of Thermal Analysis and Calorimetry 2012, 109, 1435. http://dx.doi.org/10.1007/s10973-012-2258-x

[10] Jacob G.C., Fellers J.F., Simunovk S., Sarbuck J.M.: Journal of Composite Materials 2002, 36, 813. http://dx.doi.org/10.1177/0021998302036007164

[11] Alkateb M., Mahdi E., Hamouda A.M.S., Hamdan M.M.: Composite Structures 2004, 66, 495. http://dx.doi.org/10.1016/j.compstruct.2004.04.078

[12] Alkbir M.F.M., Sapuan S.M., Nuraini A.A., Ishak M.R.: Materials \& Design 2014, 60, 85. http://dx.doi.org/10.1016/j.matdes.2014.02.031

[13] Misri S., Sapuan S.M., Leman Z., Ishak M.R.: Material \& Design 2015, 65, 953. http://dx.doi.org/10.1016/j.matdes.2014.09.073

[14] Mahdi E., Hamouda A.M.S., Sebaey T.A.: Materials \& Design 2014, 56, 923. http://dx.doi.org/10.1016/j.matdes.2013.12.009

[15] Palanivelu S., Paepegem W.V., Degrieck J. et al.: Polymer Testing 2010, 29, 381. http://dx.doi.org/10.1016/j.polymertesting.2010.01.003

[16] Ismail A.E., Hassan M.A.: Applied Mechanics and Materials 2014, 629, 503.

http://dx.doi.org/10.4028/www.scientific.net/ AMM.629.503

[17] Mahdi E., Hamouda A.M.S., Sahari B.B., Khalid Y.A.: Journal of Material Processing Technology 2003, 132, 49.
http://dx.doi.org/10.1016/S0924-0136(02)00260-1

[18] Warrior T.A., Turner E., Ribeaux Cooper M.: Thin-Walled Structures 2008, 46, 905. http://dx.doi.org/10.1016/j.tws.2008.01.023

[19] Davoodi M.M., Sapuan S.M., Ahmad D. et al.: Materials \& Design 2010, 31, 4927.

http://dx.doi.org/10.1016/j.matdes.2010.05.021

[20] Eshkoor R.A., Oshkovr S.A., Sulong A.B. et al.: Composites Part B: Engineering 2013, 55, 5. http://dx.doi.org/10.1016/j.compositesb.2013.05.022

[21] Ismail A.E., Sahrom M.F.: International Journal of Applied Engineering Research 2015, 10, 19277.

[22] Ismail A.E.: International Journal of Engineering and Technology 2015, 7, 1098.

[23] Elsaid A., Dawood M., Seracino R., Bobko C.: Construction and Building Materials 2011, 25, 1991. http://dx.doi.org/10.1016/j.conbuildmat.2010.11.052

[24] Elfetori A.E., Sulaiman S.A., Hamouda M.S., Mahdi E.: Thin-Walled Structures 2008, 46, 320. http://dx.doi.org/10.1016/j.tws.2007.07.018

[25] Jia X., Chen G., Yu Y. et al.: Composites Part B: Engineering 2013, 45, 1336. http://dx.doi.org/10.1016/j.compositesb.2012.09.060

[26] Mirfendereski L., Salimi M., Ziaei-Rad S.: International Journal of Mechanical Sciences 2008, 6, 1042. http://dx.doi.org/10.1016/j.ijmecsci.2008.02.007

[27] Reddy T.Y., Al-Hassani S.T.S.: International Journal of Mechanical Sciences 1993, 35, 231. http://dx.doi.org/10.1016/0020-7403(93)90078-9

[28] Reid S.R.: International Journal of Mechanical Sciences 1993, 35, 1035. http://dx.doi.org/10.1016/0020-7403(93)90054-X

[29] Hanssen A.G., Langseth M., Hopperstad O.S.: International Journal of Mechanical Sciences 2001, 43, 153. http://dx.doi.org/10.1016/S0020-7403(99)00108-3

[30] Eshkoor R.A., Oshkovr S.A., Sulong A.B. et al.: Materials \& Design 2013, 47, 248. http://dx.doi.org/10.1016/j.matdes.2012.11.030

[31] Farley G.L.: Journal of Composite Materials 1983, 17, 267. http://dx.doi.org/10.1177/002199838301700307

[32] Mahdi E., Hamouda A.S.M., Sen A.C.: Composite Structures 2004, 66, 647. http://dx.doi.org/10.1016/j.compstruct.2004.06.001

[33] Oshkovr S.A., Eshkoor R.A., Taher S.T. et al.: Composite Structures 2012, 94, 2337. http://dx.doi.org/10.1016/j.compstruct.2012.03.031

[34] Moon C.J., Kim I.H., Choi B.H. et al.: Composite Structures 2010, 92, 2241. http://dx.doi.org/10.1016/j.compstruct.2009.08.005

[35] Liu H.K., Liao W.C., Tseng L. et al.: Applied Science and Manufacturing 2004, 35, 281. http://dx.doi.org/10.1016/S1359-835X(03)00250-1

Received 19 IX 2017. 